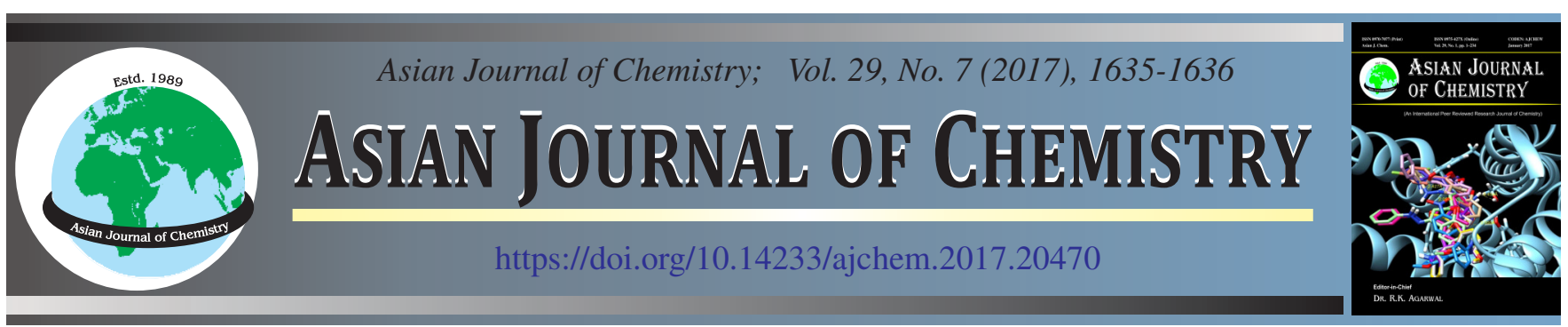

NOTE

\title{
Status of Major Nutrients in Acidic and Neutral Soils of Northern Hills Zone of Chhattisgarh State, India
}

\author{
Sonali Harinkhere*, V.K. Samadhiya, Mithun Kr. Mishra and Rakesh Giri Goswami
}

Department of Soil Science and Agricultural Chemistry, Indira Gandhi Krishi Vishwavidyalaya, Raipur-492 012, India

*Corresponding author: E-mail: harinkheresonali@gmail.com

Received: 24 December 2016;

Accepted: 11 March 2017;

Published online: 13 May 2017;

AJC-18409

\begin{abstract}
This study was aimed to obtain rice genotypes that tolerant and sensitive to acid soil. This study was conducted in two different soil $\mathrm{pH}$ condition at farmer's field at village Ajirma and research field at RMD College of Agriculture and Research Station Ajirma, Ambikapur, Chhattisgarh with twelve rice (Oryza sativa L.) genotypes laid out under randomized block design to identify the acid tolerant rice genotypes. Soil samples were collected from different locations of farmer's field $(\mathrm{pH} 4.5)$ and research field (pH 6.6) and analyzed for some important physical and chemical properties, SOC and available N, P, K. Initially, at low pH condition SOC (0.27 \%), N (151.6 kg $\left.\mathrm{ha}^{-1}\right), \mathrm{P}\left(9.63 \mathrm{~kg} \mathrm{ha}^{-1}\right), \mathrm{K}\left(148.06 \mathrm{~kg} \mathrm{ha}^{-1}\right)$ and at normal $\mathrm{pH}$ condition SOC $(0.51 \%), \mathrm{N}\left(232.6 \mathrm{~kg} \mathrm{ha}^{-1}\right), \mathrm{P}\left(14.89 \mathrm{~kg} \mathrm{ha}{ }^{-1}\right), \mathrm{K}\left(318.50 \mathrm{~kg}^{-}\right.$ $\left.\mathrm{ha}^{-1}\right)$ were analyzed.
\end{abstract}

Keywords: Oryza sativa L., Acidity tolerance, Soil fertility status, Genotypes, Organic carbon.

Rice (Oryza sativa $\mathrm{L}$ ) is one of the world's most important crops, supplying food for nearly half its population, especially in Asia. About $13 \%$ of global rice production occurs in acidic soils. Acid soils limit crop production have extended more than $40 \%$ of the world's arable soils. Aluminium toxicity is considered to be one of the most serious abiotic stress factors that limiting plant growth in acid soils [1-6]. Chhattisgarh is popularly known as "rice bowl of India". It has geographical area of 13.51 million ha of which 5.9 million ha is under cultivation [7]. Although crop production on acid soils can be sustained by application of lime, runoff pollution is an undesirable effect. Liming is often not economic or practical because of the slow movement of lime especially in the deeper layers of sub-soils. Furthermore, heavy application of lime may have adverse effects on some crops in the rotation or cause deficiencies of certain nutrients. Thus, developing cultivars with improved tolerance to acid soil stress may be a solution to address this problem [8]. Knowledge about nutrients status of the soil and their inter-relationship with physical and chemical properties is helpful in understanding the inherent capacity of soil to supply essential plant nutrients for utilization to crops. Soil fertility and nutrient supplying capacity of a soil can be maintained on a long-term basis only by replenishing, by addition through external inputs, nutrients removed by cropping and those lost through physical, chemical and biological processes. Cultivars with a high nutrient efficiency ratio when grown under acid soil stress may have an advantage in adapting to mineral-stressed acid soils and genotypes that are efficient nutrient utilizers might be useful in breeding for more efficient cultivars.

The experiment was conducted to evaluate the twelve medium duration rice genotypes laid out in Randomized Block Design with three replications in two experimental sites i.e., at farmers field at village Ajirma and research field at RMD College of Agriculture and Research Station Ajirma, Ambikapur District Surajpur, (Chhattisgarh) during kharif 2014. The experiment raised in acidic soil, sandy loam texture, $\mathrm{pH}$ (4.5) and EC $\left(0.14 \mathrm{dS} \mathrm{m}^{-1}\right)$. Available N, P and $\mathrm{K}$ status in soil was 151.60, 9.63 and $148.06 \mathrm{~kg} \mathrm{ha}^{-1}$, respectively. Soil available micronutrients i.e. $\mathrm{Cu}, \mathrm{Fe}, \mathrm{Mn}$ and $\mathrm{Zn}$ were 1.20, 88.85, 23.7 and $0.50 \mathrm{ppm}$, respectively. Likewise, in neutral soil the texture was silty clay loam, $\mathrm{pH}(6.6), \mathrm{EC}\left(0.18 \mathrm{dS} \mathrm{m}^{-1}\right)$ and available major $\left(\mathrm{kg} \mathrm{ha}^{-1}\right)$ and micro nutrient (ppm) status, $\mathrm{N}, \mathrm{P}, \mathrm{K}, \mathrm{Cu}$, $\mathrm{Fe}, \mathrm{Mn}$ and $\mathrm{Zn}$ i.e. 232.6, 14.89, 318.50, 1.60, 23.1, 11.57 and 0.60 respectively. The general recommendation doses of fertilizers were applied to the genotypes are 100:60:40. (N: $\mathrm{P}_{2} \mathrm{O}_{5}: \mathrm{K}_{2} \mathrm{O}$ ).

Available soil nirogen status: The data presented in Table-1 revealed the different levels of available nitrogen at harvest of the crop in acidic soil, the highest level of available $\mathrm{N}$ was found in treatment MTU $1010\left(177.68 \mathrm{~kg} \mathrm{ha}^{-1}\right)$ which is significantly at par with following treatments Karma Mahsuri 
TABLE-2

STATUS OF MACRONUTRIENTS AND GRAIN YIELD IN ACID AND NEUTRAL SOIL AT HARVEST

\begin{tabular}{|c|c|c|c|c|c|c|c|c|}
\hline \multirow[b]{2}{*}{ Treatments } & \multicolumn{4}{|c|}{ Acidic soils } & \multicolumn{4}{|c|}{ Neutral soils } \\
\hline & $\begin{array}{l}\text { Available } \\
\text { nitrogen } \\
\left(\mathrm{kg} \mathrm{ha}^{-1}\right)\end{array}$ & $\begin{array}{c}\text { Available } \\
\text { phosphorus } \\
\left(\mathrm{kg} \mathrm{ha}^{-1}\right)\end{array}$ & $\begin{array}{c}\text { Available } \\
\text { potassium } \\
\left(\mathrm{kg} \mathrm{ha}^{-1}\right)\end{array}$ & $\begin{array}{c}\text { Yield } \\
\left(\mathrm{q} \mathrm{ha}^{-1}\right)\end{array}$ & $\begin{array}{l}\text { Available } \\
\text { nitrogen } \\
\left(\mathrm{kg} \mathrm{ha}^{-1}\right)\end{array}$ & $\begin{array}{c}\text { Available } \\
\text { phosphorus } \\
\left(\mathrm{kg} \mathrm{ha}^{-1}\right)\end{array}$ & $\begin{array}{c}\text { Available } \\
\text { potassium } \\
\left(\mathrm{kg} \mathrm{ha}^{-1}\right)\end{array}$ & $\begin{array}{c}\text { Yield } \\
\left(\mathrm{q} \mathrm{ha}^{-1}\right)\end{array}$ \\
\hline V1-Indira Maheshwari & 175.48 & 10.10 & 151.02 & 36.96 & 253.56 & 14.47 & 324.97 & 53.78 \\
\hline V2-R-1688-2150-5-2060-1 & 163.17 & 9.61 & 152.91 & 22.76 & 250.21 & 14.58 & 327.64 & 38.58 \\
\hline V3-Sampada & 170.59 & 10.01 & 155.15 & 25.52 & 252.59 & 14.49 & 328.22 & 39.20 \\
\hline V4-Mahamaya & 173.79 & 10.06 & 158.52 & 39.35 & 246.80 & 14.51 & 323.93 & 59.64 \\
\hline V6-Vijeta (MTU 1001) & 171.32 & 10.24 & 148.95 & 26.72 & 254.60 & 14.32 & 325.07 & 44.81 \\
\hline V7-Shyamla & 167.89 & 10.16 & 151.27 & 16.81 & 251.69 & 14.61 & 328.07 & 32.17 \\
\hline V8-R 1661-605-84-1 & 176.40 & 9.92 & 155.06 & 28.27 & 254.39 & 14.53 & 324.53 & 42.85 \\
\hline V9-R 304-34 & 171.90 & 9.84 & 155.78 & 27.16 & 249.36 & 14.19 & 327.39 & 57.28 \\
\hline V10-IGKVR2 (Durgeshwari) & 176.09 & 10.34 & 153.42 & 34.03 & 253.46 & 14.42 & 329.70 & 43.98 \\
\hline V11-Karma Mahsuri & 176.76 & 9.71 & 153.84 & 33.04 & 252.44 & 14.45 & 327.79 & 38.12 \\
\hline V12-MTU 1010 & 177.68 & 9.95 & 152.86 & 37.83 & 249.77 & 14.41 & 326.44 & 47.07 \\
\hline $\mathrm{CD}(\mathrm{P}=0.05)$ & 7.59 & 0.40 & 4.73 & 2.78 & 3.24 & 0.15 & 3.28 & 8.82 \\
\hline
\end{tabular}

TABLE-1

INITIAL PHYSICO-CHEMICAL PROPERTIES OF ACID AND NEUTRAL SOIL

\begin{tabular}{lcc}
\hline \multirow{2}{*}{ Physico-chemical properties } & Acid soil & Neutral soil \\
\cline { 2 - 3 } & \multicolumn{2}{c}{ Value } \\
\hline Soil texture & 54 & 49 \\
Sand (\%) & 28 & 22 \\
Silt (\%) & 18 & 29 \\
Clay (\%) & 4.5 & 6.6 \\
$\mathrm{pH}(1: 2.5)$ & 0.14 & 0.18 \\
$\mathrm{EC}\left(\mathrm{dS} \mathrm{m}-^{-1}\right)$ & 0.27 & 0.51 \\
Organic carbon $(\%)$ & 151.6 & 232.6 \\
Available nitrogen $\left(\mathrm{kg} \mathrm{ha}^{-1}\right)$ & 9.63 & 14.89 \\
Available phosphorus $\left(\mathrm{kg} \mathrm{ha}^{-1}\right)$ & 148.06 & 318.50 \\
Available potassium $\left(\mathrm{kg} \mathrm{ha}^{-1}\right)$ & &
\end{tabular}

$>$ R 1661-605-84-1 > Durgeshwari > Indira Maheshwari > Bamleshwari $>$ Mahamaya $>$ R 304-34 > Vijeta and the lowest level of available $\mathrm{N}$ is observed in treatment $\mathrm{R}-1688-2150-5-$ 2060-1 (163.17 kg ha-1).

The results presented in Table- 2 on available $\mathrm{N}$ in neutral soil revealed that the treatment Vijeta $\left(254.60 \mathrm{~kg} \mathrm{ha}^{-1}\right)$ which was significantly at par with following treatments $\mathrm{R} 1661$ 605-84-1 > Indira Maheshwari > Durgeshwariu > Sampada > Karma Mahsuri > Shayamla and the lowest level of available $\mathrm{N}$ was observed in treatment Mahamaya (246.80 $\left.\mathrm{kg} \mathrm{ha}^{-1}\right)$.

Available soil phosphorus status: The data presented on Table-1 revealed that available $\mathrm{P}$ at harvest in acidic soil was maximum in Durgeshwari $\left(10.34 \mathrm{~kg} \mathrm{ha}^{-1}\right)$ which was significantly superior and at par with Vijeta $>$ Bamleshwari $>$ Shyamla $>$ Indira Maheshwari > Mahamaya > Sampada > MTU 1010 and the minimum level of available $\mathrm{P}$ was observed in R-16882150-5-2060-1 (9.61 kg ha $\left.{ }^{-1}\right)$, whereas in neutral soil Table-2 available $\mathrm{P}$ was found maximum in Shyamla (14.61 $\left.\mathrm{kg} \mathrm{ha}^{-1}\right)$ which was significantly superior and at par with R-1688-21505-2060-1 > R 1661-605-84-1 > Mahamaya > Sampada > Indira Maheshwari $>$ Bamleshwari and the minimum level of available P was observed in R-304-34 (14.19 kg ha-1).
Available soil potassium status: The soil available $\mathrm{K}$ status in acid soil Table-1 was found maximum in Mahamaya $\left(158.52 \mathrm{~kg} \mathrm{ha}^{-1}\right)$ which was significantly superior and at par with R-304-34 > Sampada > R 1661-605-84-1 > Bamleshwari $>$ Karma Mahsuri and the minimum level of available K was observed in Vijeta (148.95 $\left.\mathrm{kg} \mathrm{ha}^{-1}\right)$.

Whereas, in neutral soil Table-2 stated that in neutral soil condition available $\mathrm{K}$ was found maximum in Durgeshwari (329.70 $\mathrm{kg} \mathrm{ha}^{-1}$ ) which was significantly superior and at par with Sampada > Shyamla > Karma Mahsuri > R-1688-21505-2060-1 > R-304-34 > MTU 1010 and the minimum level of available $\mathrm{K}$ was observed in Mahamaya (323.93 $\mathrm{kg} \mathrm{ha}^{-1}$ ).

\section{ACKNOWLEDGEMENTS}

The authors are thankful to the IGKV, Raipur and RMD, CARS, Ambikapur, India for providing field and laboratory facilities.

\section{REFERENCES}

1. L. Simon, M. Kieger, S.S. Sung and T.J. Smalley, J. Plant Nutr., 17, 307 (1994);

https://doi.org/10.1080/01904169409364729.

2. S. Doncheva, M. Amenós, C. Poschenrieder and J. Barceló, J. Exp. Bot., 56, 1213 (2005);

https://doi.org/10.1093/jxb/eri115.

3. C. Poschenrieder, B. Gunsé, I. Corrales and J. Barceló, Sci. Total Environ., 400, 356 (2008); https://doi.org/10.1016/j.scitotenv.2008.06.003.

4. S. Zhou, R. Sauvé and T.W. Thannhauser, J. Exp. Bot., 60, 1849 (2009); https://doi.org/10.1093/jxb/erp065.

5. M.N. Alvim, F.T. Ramos, D.C. Oliveira, R.M.S. Isaias and M.G.C. Franca, J. Biosci., 37(S1), 1079 (2012); https://doi.org/10.1007/s12038-012-9275-6.

6. P. Pandey, R.K. Srivastava and R.S. Dubey, Ecotoxicology, 22, 656 (2013); https://doi.org/10.1007/s10646-013-1058-9.

7. Anonymous, Directorate of Economics and Statistics, New Delhi, pp. 14-15 (2011).

8. A. Kumar, A. Pandey and A. Pattanayak, Indian J. Genet. Plant Breed., 73, 153 (2013); https://doi.org/10.5958/j.0975-6906.73.2.022. 